\title{
Comparison between the productivity of pure and mixed stands of Norway spruce and European beech along an ecological gradient
}

\author{
Hans PretzSCH ${ }^{1 *}$, Joachim Block ${ }^{2}$, Jochen DieleR ${ }^{1}$, Phan Hoang DoNG ${ }^{2}$, Ulrich KoHNLE ${ }^{3}$, \\ Jürgen NAGEL ${ }^{4}$, Hermann SPELlMANN ${ }^{4}$, Andreas ZINGG ${ }^{5}$ \\ ${ }^{1}$ Chair for Forest Growth and Yield Science, Technische Universität München, Hans-Carl-von-Carlowitz-Platz 2, \\ 85354 Freising-Weihenstephan, Germany \\ ${ }^{2}$ Research Institute for Forest Ecology and Forestry Rhineland-Palatinate, Trippstadt, Germany \\ ${ }^{3}$ Forest Research Station Baden-Württemberg, Freiburg, Germany \\ ${ }^{4}$ Northwest German Forest Research Station, Göttingen, Germany \\ ${ }^{5}$ Swiss Federal Research Institute WSL, Birmensdorf, Schweiz
}

(Received 21 September 2009; accepted 1 February 2010)

Keywords:

facilitation /

competitive reduction /

overyielding /

underyielding /

mixing effect /

long-term mixing experiments /

Picea abies /

Fagus sylvatica

\begin{abstract}
- Existing growth and yield plots of pure and mixed stands of Norway spruce (Picea abies (L.) H. Karst.) and European beech (Fagus sylvatica L.) were aggregated in order to unify the somewhat scattered sources of information currently available, as well as to develop a sound working hypothesis about mixing effects. The database contains information from 23 long-term plots, covering an ecological gradient from nutrient poor and dry to nutrient rich and moist sites throughout Central Europe.

- An empirically formed interaction model showed, that depending on the site conditions, dry mass growth in mixed stands can range from $-46 \%$ to $+138 \%$ of the growth yielded by a scaled combination of pure stands at equal mixing proportions.

- Drawing from the interaction model, overyielding of the mixed stands appears to be triggered by two separate mechanisms. On poor sites, where significant overyielding is commonly found, facilitation by beech offsets nutrient-related growth limitations in spruce. In contrast, overyielding of mixed stands occurs less frequently on rich sites, and appears to be based on an admixture effect, with spruce reducing the severe intra-specific competition common in pure beech stands.

- It was concluded that silviculture can accelerate growth of spruce by beech admixtures on poor sites, while growth of beech can be promoted by admixture of spruce, particularly on excellent sites.
\end{abstract}

\section{INTRODUCTION}

The controversial discussion regarding whether mixed stands are more productive than pure stands dates back to the founding fathers of forest science in Europe. Cotta (1828, p. 115) concluded that mixed stands are indeed more productive, whereas Hartig (1791, p. 134) asserted that this was not the case. Although numerous comparative studies have been carried out for mixing of Norway spruce (Picea abies (L.) H. Karst.) and European beech (Fagus sylvatica L.) at a stand level, no conclusive modeling concept has yet been formed, despite the fact that this mixture has been exhaustively analyzed throughout Central Europe (Assmann, 1961; Burger, 1941; Kennel, 1965; Mettin, 1985; Petri, 1966; Wiedemann, 1942). The question whether mixed stands are more productive than pure stands thus remains open. Recent studies at individual and bio-group levels revealed numerous fascinating traits exhibited by tree species growing in mixture (Kelty

*Corresponding author: h.pretzsch@1rz.tum.de und Cameron, 1995; Rothe, 1997; Pretzsch und Schütze, 2005; 2009), but such refined analyses at tree or organ levels have, to date, failed to demonstrate a general relationship between the productivity of mixed and pure stands (Scherer-Lorenzen et al., 2005).

The reasons for the lack of information on mixing effects and their interaction with site-specific factors lies most probably in the somewhat unfocused and inconsistent nature of research approaches previously applied. Petri (1966) analyzed structural differences between pure and mixed stands, Kennel (1965) documented differences in growth and yield at three sites in Germany, and von Lüpke and Spellmann (1997) and Spellmann (1996) compared volume productivity, stability, and stem quality of pure and mixed stands. To further hinder efforts to aggregate these studies, reports are usually based on different and incompatible evaluation methods. Some reports on interactions in mixed stands refer to neighboring pure stands of each species on the same site (Kennel, 1965), while others compare the observed growth of mixed stands to 
an amalgam of growth data observed in pure stands of one species and yield table expectations of the other (Wiedemann, 1942; 1951). Furthermore, mixing effects are inconsistently addressed through different growth indicators, such as stem volume growth (Rothe, 1997; Wiedemann, 1942), stem dry mass growth (Kennel, 1965), or total above ground dry mass growth (Pretzsch and Schütze, 2005; 2009), thus rendering comparisons of the results obtained in the different studies extremely tedious. The rather few existing long-term observation plots are scattered throughout a patchwork of nations, state administrations, and research institutions, further impeding a comprehensive evaluation along an ecological gradient.

The heterogeneous results of previous mixed stand research have been reviewed exhaustively (Kelty, 1992; Olsthoorn et al., 1999; Pretzsch, 2005) and will not be repeated here, nor will this study contribute just another isolated study to the already scattered array of information available on the topic. An attempt will rather be made, to aggregate the existing reports and studies on growth and yield plots of pure and mixed stands of spruce and beech. This information will then be used to unify the scattered yet undoubtedly abundant knowledge on this topic into a sound working hypothesis about the interaction of mixing effects and site conditions. Using results already published, newly established mixed stand plots in the German state of Bavaria, as well as datasets from German forest research stations in the states of Lower Saxony (Göttingen), Rhineland-Palatinate (Trippstadt), BadenWürttemberg (Freiburg), as well as in Switzerland (Birmensdorf), a dataset covering a broad range of site conditions will be compiled in order to answer two fundamental questions:

(1) To what extent does overyielding or underyielding occur in mixed stands compared to pure stands?

(2) How do site conditions or mixing proportions impact overyielding or underyielding?

Through a comprehensive analysis of growth patterns displayed on different sites, the already documented yet seemingly contradictory results from individual case studies will be compiled into a dataset, containing a continuum of growth pattern information from nutrient poor and dry to nutrient rich and moist sites. Through this approach, an attempt will be made to (a) disclose statistical relationships between mixing effects and site conditions, (b) form the basis for a causal interpretation, and (c) develop a working hypothesis for further research on the growth dynamics of mixed stands.

\section{MATERIALS AND METHODS}

To test hypotheses on forest stand dynamics, long-term observations on a full set of permanent plots kept under standardized treatment programs were required. Since the foundation of the "Verein Deutscher Forstlicher Versuchsanstalten" (Association of German Forest Research Stations) in 1872 and its international successor organization "International Union of Forest Research Organizations" (IUFRO) in 1892, central European research institutions have been cooperating with the institution of standardized research plans, allowing for compilation of trans-institutional trial series. This paper is a result of this long-term process of observation and cooperation. Its added value is the wide ecological gradient through which it operates, which could only be achieved by pooling datasets of several research organizations. The data is based mainly on information from research plots, which were established, treated and measured by previous generations of forest researchers to whom we are deeply grateful.

\subsection{Material and methods}

For this study, data from long-term observation plots in pure and mixed stands of Norway spruce and European beech in Switzerland, Poland, and the German states of Bavaria, Baden-Württemberg, Hessen, Rhineland-Palatinate, North Rhine-Westfalia, Lower-Saxony was pooled, in order to cover a broad range of site conditions (Tab. S1, available at www.afs-journal.org). The covered area spans a distance of about $600 \mathrm{~km}$ (latitudes $46^{\circ}$ to $51^{\circ} \mathrm{N}$ ) and $700 \mathrm{~km}$ from east to west (longitudes $7^{\circ}-16^{\circ} \mathrm{E}$ ) (Fig. 1). The plots are located in altitudes ranging from 150 to $800 \mathrm{~m}$, with annual mean local temperatures ranging from 5.5 to $8.5^{\circ} \mathrm{C}$, and annual precipitation between 700 and $1270 \mathrm{~mm}$. The warmer and drier sites in Silesian, as well as the cooler and moister regions in the Bavarian Forest are included in the study. The best site conditions and highest growth rates are represented on moist and fertile sites in the pre-alpine lowland zone of the German state of Bavaria.

With only a few exceptions, the included test sites comprised one plot with pure spruce, one with pure beech, and one or more plots where both species grow. In total, 23 test sites were included in the study. Stands of pure spruce, pure beech, as well as mixed spruce/beech were compared in 52 triplets. In total, the data set covered 207 survey periods, the oldest records dating back to 1895 and the most recent to 2009. Stand age ranges from 33 to $150 \mathrm{y}$ (see Tab. S1, available at www.afs-journal.org) The oldest plots delivered data from up to 16 surveys, while those most recently established contributed data from just a single survey period. The measurement intervals range from 5 to 15 years. The mixing proportions of the respective species $\left(m_{\mathrm{sp}}, m_{\mathrm{be}}\right)$ were calculated based on their share of above ground dry mass (see Sect. 2.2) and cover in the mixed plots at tree mixing proportions ranging from $m_{\mathrm{sp}}: m_{\mathrm{be}}=0.05: 0.95$ to $m_{\mathrm{sp}}: m_{\mathrm{be}}=0.95: 0.05$, although in most mixed plots the species proportion approached $m_{\mathrm{sp}}: m_{\mathrm{be}}=0.5: 0.5$.

Most of the analyzed stands stemmed from natural regeneration, are within the species more or less even aged, with European beech leading in age over Norway spruce by 5 to 10 years (see Tab. S2, available at www.afs-journal.org). The experimental plots established prior to 1950 were retrospectively defined in already existing stands, which were most suited to studies aimed at assessing mixing effects. Most of the younger plots were established in stands for the specific purpose of long-term analysis of mixing effects. Only plots without a history of severe natural disturbances (i.e. windthrow, bark beetle invasion, icebreakage, etc.) and with light to moderate thinning were included in this study.

The compilation of the growth characteristics of pure stands of the two species compared at identical locations (Fig. 2) demonstrates the considerable range of growing conditions covered by the observation plots. To illustrate, in the pure Norway spruce stands, the maximum height reached at age 100 (Fig. 2a) ranged for $h_{\mathrm{o}}$ from 19.7 to $52.1 \mathrm{~m}$ (mean $h_{\mathrm{o}}=35.1 \mathrm{~m}$ ), and in the pure European beech stands the top height ranged from 18.8 to $45.1 \mathrm{~m}$ (mean $h_{\mathrm{o}}=29.9 \mathrm{~m}$ ). The periodic mean annual increment of stem volume was PAIV sp $=4.8-36.5 \mathrm{~m}^{3} \mathrm{ha}^{-1} \mathrm{y}^{-1}$ on the pure spruce plots (mean $14.7 \mathrm{~m}^{3} \mathrm{ha}^{-1} \mathrm{y}^{-1}$ ) and PAIV $\mathrm{be}=4.3-29.9 \mathrm{~m}^{3} \mathrm{ha}^{-1} \mathrm{y}^{-1}$ in the case 


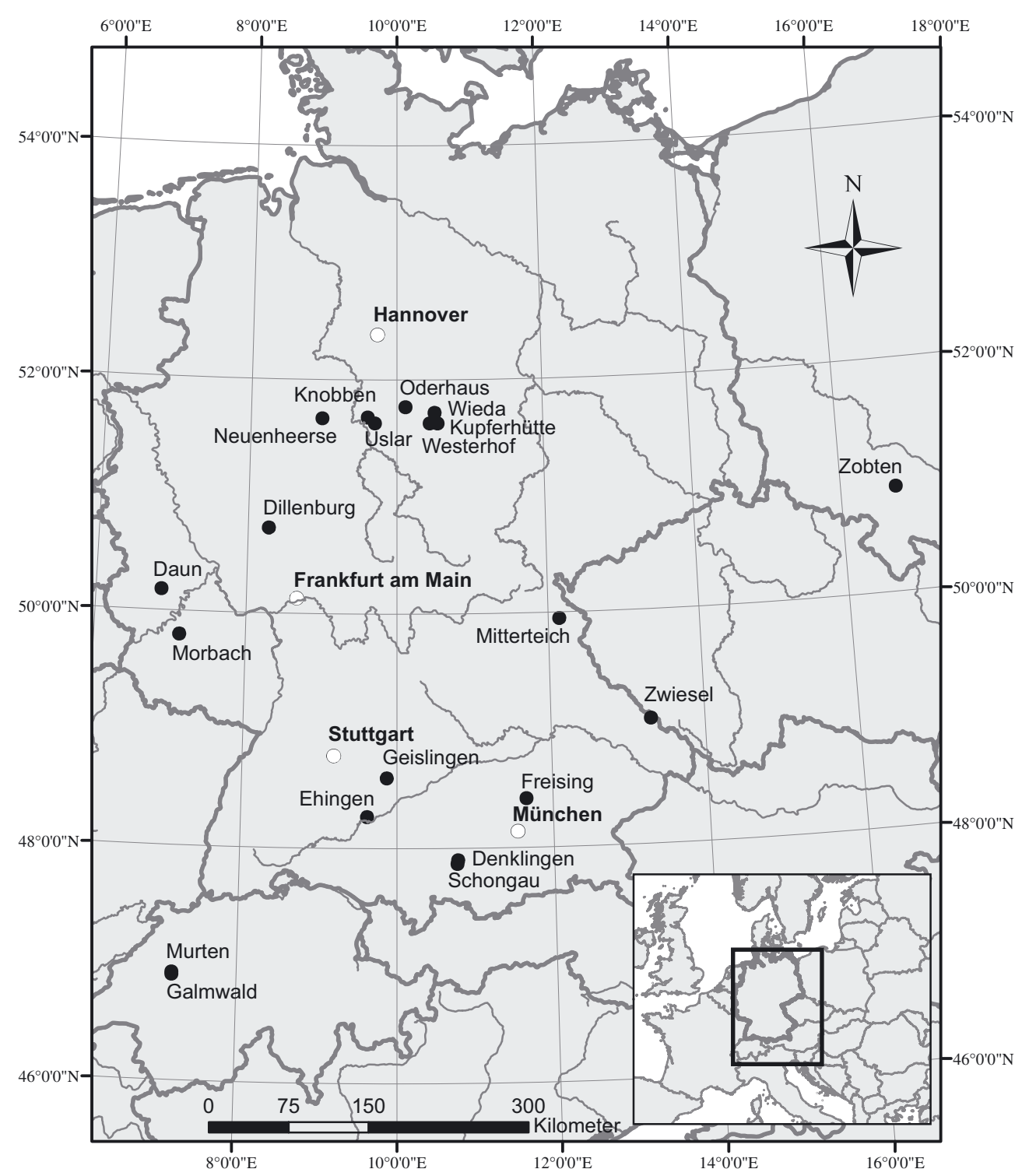

Figure 1. Location of the 23 long-term mixed stand observation plots of pure Norway spruce, pure European beech, and mixture of Norway spruce and European beech included in this study.

of beech (mean $10.5 \mathrm{~m}^{3} \mathrm{ha}^{-1} \mathrm{y}^{-1}$ ). The ratio PAIV $\mathrm{sp}$ : PAIV be ranged mostly from $0.5: 1.0$ to $2.5: 1$ and clearly demonstrated that our dataset covered a much wider range of competitive strength between Norway spruce and European beech than the data used by Assmann (1961, pp. 351-353). In particular, a number of trials (e.g. from the limestone region of the Jurassic Swabian Alb, and the basalt region of Mitterteich) where European beech substantially dominated Norway spruce in terms of growth on the same site were included in the study. For a detailed overview on the data analyzed in this study see Tabs. SI and SII, available at www.afs-journal.org.

Due to the wide range of site conditions, the size growth rates of spruce and beech differed considerably. The mean diameter in the mixed stand could deviate from the neighboring pure stands by factors ranging from just 0.5 to as high as 1.5 (Fig. S1, available at www. afs-journal.org). On average, mean diameter of spruce amounted to $34.0 \mathrm{~cm}$ in the mixture, compared to $30.4 \mathrm{~cm}$ in the pure stands, equivalent to a superiority of the mixed stand by $12 \%$. In contrast, beech achieved an average diameter of $21.9 \mathrm{~cm}$ in the mixed stands and $23.1 \mathrm{~cm}$ in the pure stand.

\subsection{Method for analyzing the mixing effect}

The evaluation carried out in this study was arranged in triplet experimental setups, where one plot represented pure Norway spruce, one pure European beech, and a third containing both species in mixture. Stand productivity $(\mathrm{p})$ was analyzed on the basis of both the periodic annual increment of stem volume (PAIV in $\mathrm{m}^{3} \mathrm{ha}^{-1} \mathrm{y}^{-1}$; total stem volume with diameter $\geq 7 \mathrm{~cm}$ over bark in the case of spruce, and merchantable stem volume $\geqslant 7 \mathrm{~cm}$ over bark in the case of beech) and the periodic annual increment of above ground dry mass weight (PAIW in $\mathrm{t} \mathrm{ha}^{-1} \mathrm{y}^{-1}$ ). The measurement intervals for calculation 


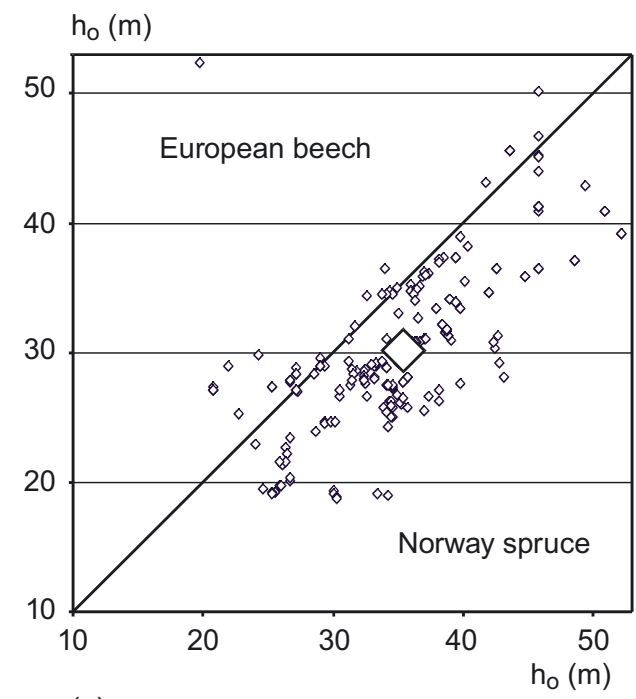

(a)

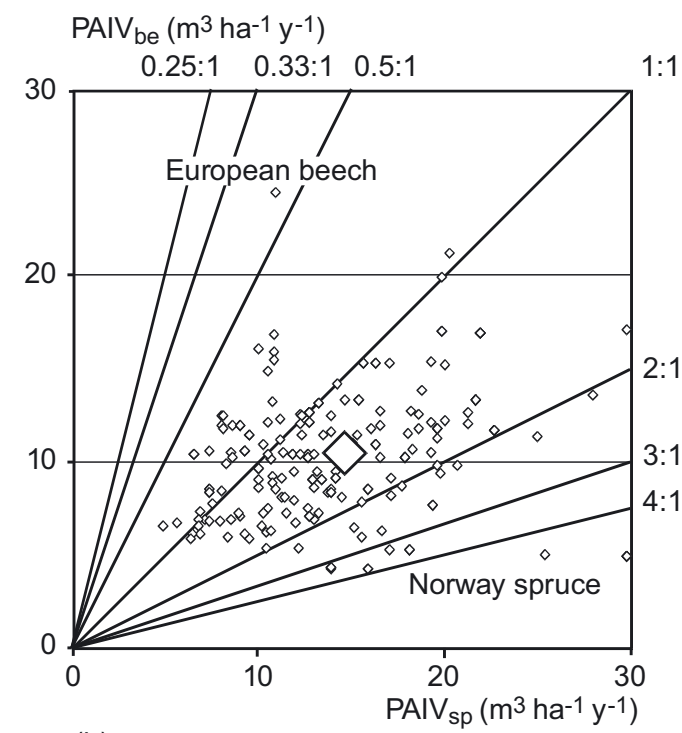

(b)

Figure 2. Characteristics of the Norway spruce and European beech pure stands which serve as reference for revelation of mixing effects on the neighbouring mixed plots. Shown is (a) top height $h_{\mathrm{o}}$ at age 100 and (b) periodic mean annual volume increment PAIV. The large rhombi indicate the species-specific mean values of $\mathrm{h}_{o}$ (N. sp. $35.1 \mathrm{~m}$; E. b. 29.9 m) and PAIV (N. sp. $14.7 \mathrm{~m}^{3} \mathrm{ha}^{-1} \mathrm{y}^{-1} ; \mathrm{E}^{\text {b. }} 10.5 \mathrm{~m}^{3}$ ha $\mathrm{a}^{-1} \mathrm{y}^{-1}$ ).

of the periodic annual increment range from 5 to 15 years. Above ground dry mass was estimated on an individual tree basis with the use of dry mass functions for Norway spruce and European beech $\left(w=0.044 d^{2.659}\right.$ and $w=0.114 d^{2.503}$ respectively, with $\mathrm{w}$ representing above ground dry mass, and d representing stem diameter at a height of $1.3 \mathrm{~m}$ (see Pretzsch and Schütze, 2005)) which were derived by dry mass analysis on long-term experimental plots, including those of this study. Total stand above ground dry mass was measured as the sum of individual tree dry mass.

The productivity of the pure Norway spruce stands is denoted as $p_{\text {sp }}$, the European beech stand as $p_{\text {be }}$, and the mixed stand as $p_{\text {sp.be }}$. The productivity per ha of Norway spruce in the mixed stand is no-

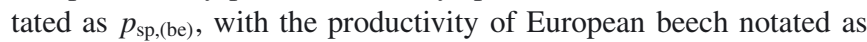

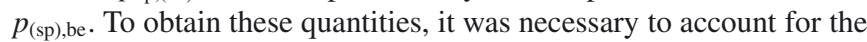
share of productivity $p p_{\mathrm{sp},(\mathrm{be})}$ and $p p_{(\mathrm{sp}), \mathrm{be}}$ of both species, as well as their mixing proportions $m_{\mathrm{sp}}$ and $m_{\mathrm{be}}$. With this in mind, the mixing proportions were calculated in this study based on the species' share of the total above ground dry mass at the beginning of the respective survey period. This made it possible to solve $p_{\mathrm{sp},(\mathrm{be})}=p p_{\mathrm{sp},(\mathrm{be})} / m_{\mathrm{sp}}$ and $p_{(\mathrm{sp}), \mathrm{be}}=p p_{(\mathrm{sp}), \mathrm{be}} / m_{\mathrm{be}}$. The shares $p p_{\mathrm{sp},(\mathrm{be})}$ and $p p_{(\mathrm{sp}), \mathrm{be}}$ represent the contributions of Norway spruce and European beech to the productivity in the mixed stand, giving $p_{\mathrm{sp}, \mathrm{be}}=p p_{\mathrm{sp},(\mathrm{be})}+p p_{(\mathrm{sp}), \mathrm{be}}$. Additionally, $p_{\mathrm{sp},(\mathrm{be})}$ reflects the contribution $p p_{s p,(b e)}$ scaled up to 1 ha by the mixing proportion of this species, thus $p_{\mathrm{sp},(\mathrm{be})}=\mathrm{pp} \mathrm{pp},(\mathrm{be}) / \mathrm{m}_{\mathrm{sp}}$. From this follows

$$
\hat{p}_{\text {sp,be }}=p_{\text {sp }} m_{\text {sp }}+p_{\text {be }} m_{\text {be }}
$$

which represents the expected productivity of a mixed stand, assuming that the growth dynamics exhibited by both species in pure stands were not impacted by the presence of the other species. If the observed productivity $p_{\text {sp,be }}$ in the mixed stand is higher than this expected productivity $\hat{p}_{\text {sp,be }}$,

$$
p_{\text {sp,be }}>\hat{p}_{\text {sp,be }}
$$

overyielding occurs. Furthermore, even if

$$
p_{\text {sp,be }}>p_{\text {sp }} \quad \text { and } \quad p_{\text {sp,be }}>p_{\text {be }}
$$

transgressive overyielding of the mixed stand with reference to both of the species in pure stands is observed. Underyielding on the other hand is indicated by $p_{\text {sp,be }}<\hat{p}_{\text {sp,be }}$, while $p_{\text {sp,be }}<p_{\text {sp }}$ and $p_{\text {sp,be }}<p_{\text {be }}$ shows transgressive underyielding (Pretzsch, 2009, pp. 352-354).

The following quotients of the previous variables apply for the comparison between pure and mixed stands: The ratio $p_{\mathrm{sp}}: p_{\mathrm{be}}$ compares the productivity of the considered species in a monoculture. The ratio $p_{\mathrm{sp},(\mathrm{be})}: p_{(\mathrm{sp}), \mathrm{be}}$ defines the same relationship for mixed stand. The latter reveals how mixing changes the relative strength of both species. Absolute over- or underyielding can be quantified by

$$
\mathrm{MEA}=p_{\text {sp,be }}-\hat{p}_{\text {sp,be }}
$$

(MEA, i.e. mixing effect absolute) and relative over- or underyielding by the ratio

$$
\mathrm{MER}=p_{\text {sp,be }}: \hat{p}_{\text {sp,be }}
$$

(MER, i.e. mixing effect relative). Equation (5) results in unity when the mixed stand grew as expected from the observations of the neighboring pure stands. Values above or below unity indicate and quantify the extent of relative over- or underyielding. When $p_{\mathrm{sp}, \mathrm{be}}: \hat{p}_{\mathrm{sp}, \mathrm{be}}=1.5$, overyielding is $50 \%$. The ratios $p_{\mathrm{sp},(\mathrm{be})}: p_{\mathrm{sp}}$ and $p_{(\mathrm{sp}), \mathrm{be}}: p_{\text {be }}$ can therefore identify which species is causing the over- or underyielding effect. These ratios also relate each species' productivity per ha in mixed stands to its production per ha in the neighboring monoculture.

The variables $h_{\mathrm{o} \text { sp }}$ and $h_{\mathrm{o} \text {,be }}$, which are used for analyzing any dependencies between mixing effect and site index, represent the maximum height of Norway spruce and European beech at an age of 100 years (see Pretzsch, 2009, pp. 200-203 for the definition and calculation of $h_{\mathrm{o}}$ ). As most of the survey series included species up to the age of 100 the $h_{\mathrm{o}, \mathrm{sp}}$ and $h_{\mathrm{o} \text {,be }}$ values measured on the pure stand plots were used. For plots younger than 100 years, the site index was 
referenced or extra-polated from yield tables by Assmann and Franz (1965) and Schober (1975).

All evaluations were carried out in SPSS, Version 17.0. For fitting models (6) and (7) we applied the nonlinear regression procedure based on the Levenberg-Marquardt algorithm.

\section{RESULTS}

Over and underyielding by mixing is reported to occur for both the periodic annual growth of stem volume $\left(\mathrm{m}^{3} \mathrm{ha}^{-1} \mathrm{y}^{-1}\right)$ and growth of above ground dry mass $\left(\mathrm{t} \mathrm{ha}^{-1} \mathrm{y}^{-1}\right)$. While volume data is more relevant to applied forestry, information about dry mass is more suitable for ecological research. The impact of site conditions and mixing proportion on productivity is therefore analyzed on the basis of periodic annual growth of above ground dry mass.

On average, total standing volume of spruce per hectare stand surface was lower in the mixed stand compared to the pure stand, while the opposite was true for beech (Fig. 3a and $3 b$ ). Total standing volume amounted to $421 \mathrm{~m}^{3} \mathrm{ha}^{-1}$ in the mixed stands, and $434 \mathrm{~m}^{3} \mathrm{ha}^{-1}$ in the pure stands, resulting in a marginal $3 \%$ lower volume for the mixed stands. There were however no significant differences with respect to standing above ground dry mass, with values of $254 \mathrm{tha}^{-1}$ in mixed stands and $255 \mathrm{~m}^{3} \mathrm{ha}^{-1}$ in pure stands (Fig. S2, available at www.afs-journal.org).

\subsection{How does the productivity of mixed stands compare to adjacent pure stands?}

Figure 4a shows the observed PAIV $\left(\mathrm{m}^{3} \mathrm{ha}^{-1} \mathrm{y}^{-1}\right)$ values of the mixed stands plotted against the expectation value $\hat{P}_{\text {AIV }}$ sp,be derived from the respective pure stands. The closer a given value is to the bisection line, the lower is the overall effect of the mixture on the respective stand's productivity. The mixed stands produce on average $0.51 \mathrm{~m}^{3} \mathrm{ha}^{-1} \mathrm{y}^{-1}$ more than what is expected from pure stands. The maximum overyielding observed for mixed stands is $11.06 \mathrm{~m}^{3} \mathrm{ha}^{-1} \mathrm{y}^{-1}$, and maximum underyielding is $7.23 \mathrm{~m}^{3} \mathrm{ha}^{-1} \mathrm{y}^{-1}$.

Figure $4 \mathrm{~b}$ shows the relative over- and underyielding on the basis of the relative periodic mean annual increment of above ground dry mass weight of the mixed stands compared with the expectation based on the pure stands $\left(\mathrm{MERW}_{\mathrm{sp}, \mathrm{be}}=\right.$ PAIW $_{\text {sp.be }}: \hat{P}_{\text {AIW }}$ sp,be). In a case where the mixing effect is absent, these values would correspond to the $\mathrm{MERW}_{\text {sp,be }}=1$ line, which represents a simple species replacement effect. Positive or negative deviations would represent over or underyielding, respectively. The mean relative mixing effect is 1.08 , suggesting that on average the mixed stands in our dataset produce $8 \%$ more above ground dry mass than the pure stands. However, it was also noticed that relative mixing effects of up to 2.38 (overyielding of $138 \%$ ) and as low as -0.54 (underyielding of $46 \%$ ) did occur.

While most of the previous studies have focused on the comparison of Norway spruce performance in pure and mixed stands, the data presented in this study additionally provides a comparison of beech performance in pure and mixed stands. Figure 5 shows the absolute and relative mixing effects individually for Norway spruce and European beech. The stem volume increment of spruce in mixed stands (Figs. 5a and $5 \mathrm{~b}$ ) is on average $0.94 \mathrm{~m}^{3} \mathrm{ha}^{-1} \mathrm{y}^{-1}$ lower than that of the neighboring pure spruce stands. Individual mixing effects range from $+13.11 \mathrm{~m}^{3} \mathrm{ha}^{-1} \mathrm{y}^{-1}$ to $-16.81 \mathrm{~m}^{3} \mathrm{ha}^{-1} \mathrm{y}^{-1}$. The mean relative mixing effects based on dry mass production is 1.01, with individual values ranging from 0.43 to 2.41 . The absolute periodic mean annual volume increment of beech (Figs. 5c and 5d) exceeds the increment values observed in the pure stand by an average of $2.65 \mathrm{~m}^{3} \mathrm{ha}^{-1} \mathrm{y}^{-1}$, with positive effects as high as $+14.82 \mathrm{~m}^{3} \mathrm{ha}^{-1} \mathrm{y}^{-1}$ and negative effects reaching $-6.94 \mathrm{~m}^{3} \mathrm{ha}^{-1} \mathrm{y}^{-1}$. The relative mixing effects amount to an average 1.41 , with a range from 0.42 to 4.80 .

All plots where natural disturbances or heavy thinning caused a more long-term interruption to the canopy closure were removed from the dataset. The analysis of mixing effects is thus based solely on stable stands with medium to high stand density, where the growth rates and yield are not determined to a significant degree by density effects (Pretzsch, 2009, p. 348).

\subsection{Impact of site conditions and mixing proportion on productivity}

The effect of site index $\left(h_{\mathrm{o}}\right)$ and mixing proportion $\left(m_{\mathrm{sp}}\right.$, $m_{\mathrm{be}}$ ) on the relative mixing effect of Norway spruce and European beech $\left(\mathrm{MERW}_{\mathrm{sp},(\mathrm{be})}, \mathrm{MERW}_{(\mathrm{sp}), \mathrm{be}}\right)$ with respect to dry mass growth (overyielding, neutral effect, underyielding) can be described statistically by the following functions (standard error of the parameters in brackets):

$$
\begin{aligned}
\operatorname{MERW}_{\mathrm{sp},(\mathrm{be})}= & 1+1.347( \pm 0.373) \times m_{\mathrm{be}}-0.033( \pm 0.010) \\
& \times m_{\mathrm{be}} \times h_{\mathrm{o}, \mathrm{sp}} \\
\left(n=189, R^{2}=\right. & 0.21, p<0.05) \\
\operatorname{MERW}_{(\mathrm{sp}), \mathrm{be}}= & 1-0.898( \pm 0.298) \times m_{\mathrm{sp}}+0.055( \pm 0.009) \\
& \times m_{\mathrm{sp}} \times h_{\mathrm{o}, \mathrm{be}} \\
\left(n=169, R^{2}=\right. & 0.48, p<0.01) .
\end{aligned}
$$

The models as a whole (formulas (6) and (7)), as well as all included parameters are at least significant at level $p<0.05$. By using 1.0 as intercept the model ensures that the relative mixing effect amounts to 1.0 (no effect) when the mixing proportions $m_{\text {be }}$ or $m_{s p}$ are 0 . The slope of the second term in formulas (6) and (7) expresses the direct effect of different mixing proportions on MERW. In addition we found an interaction effect between mixing proportion and site index on MERW which is reflected by the slope of the third term. Other independent variables or variable combinations were tested but did not improve the model.

Depending on the respective site conditions, mixtures of European beech and Norway spruce at varying proportions may result in both positive and negative effects on overall stand productivity (Fig. 6a). On poor sites, admixture of beech in general appears to trigger a positive effect, which increases with the number of beech individuals introduced into the 


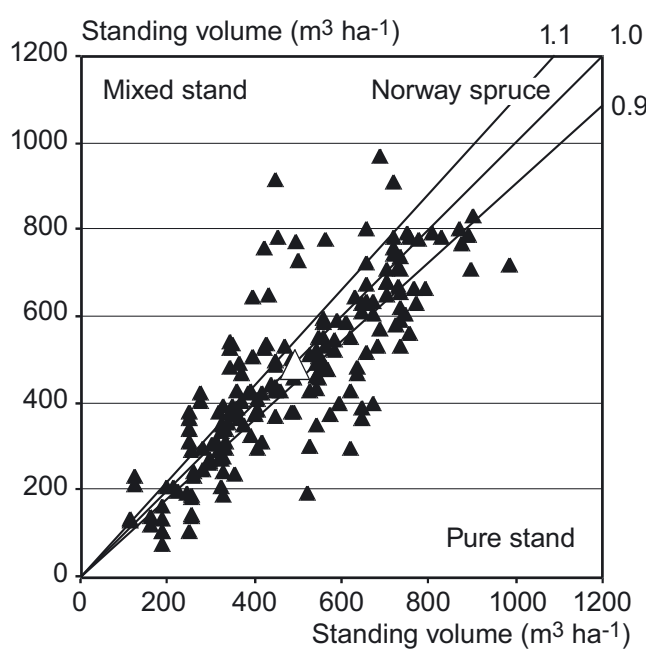

(a)

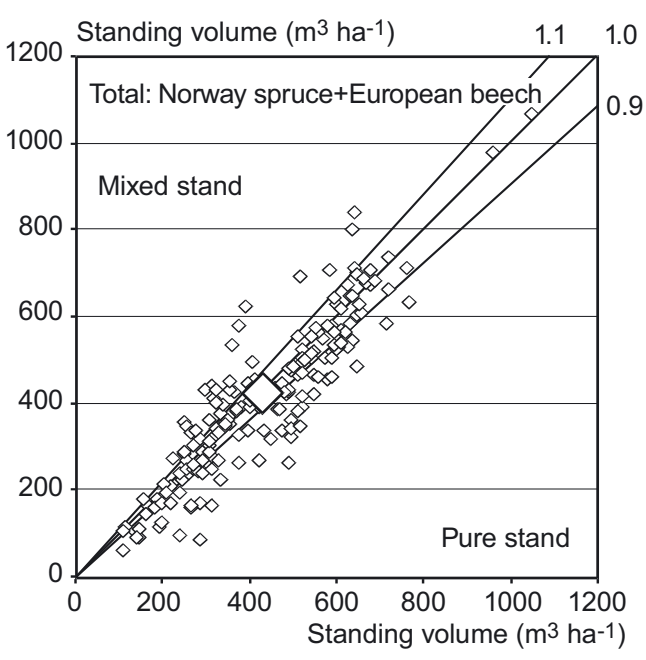

(c)

stand. In contrast, on sites with high growth performance of spruce trees, admixtures of beech more commonly appear to cause negative effects on overall stand productivity. On intermediate sites however, the balance of potential mixing effects appears rather neutral and corresponds to a simple replacement of the two species.

In beech stands a different reaction pattern can be observed (Fig. 6b), where the effect of spruce admixtures is also dependent on the site index. However, on sites with poor productivity of beech, the effect of spruce admixtures is much less pronounced than on fertile sites. Furthermore, the response of beech stands is much more pronounced and generally stronger than in spruce stands.

It is to be emphasized that these statistical relationships, though significant, are relatively weak. As a result, the findings of this study are interpreted as a sound basis for a working hypothesis rather than conclusive results calling for generalizations and predictions.

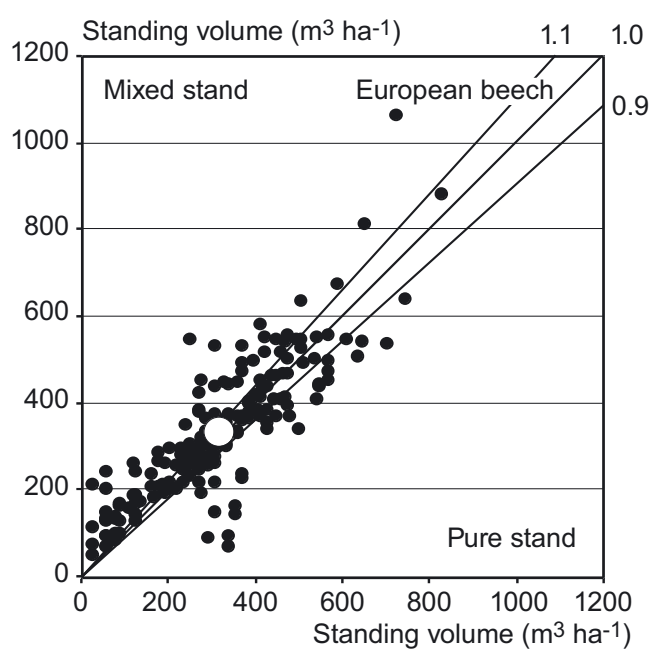

(b)

Figure 3. Comparison between the standing stem volume in mixed and pure stand. Standing volume of (a) Norway spruce, (b) European beech, and (c) total stand in the mixed stand over the reference values for the pure stand. For the mean total stand standing volume (rhombus) $421 \mathrm{~m}^{3} \mathrm{ha}^{-1} \mathrm{y}^{-1}$ where measured while $434 \mathrm{~m}^{3} \mathrm{ha}^{-1} \mathrm{y}^{-1}$ are expected on the basis of the neighbouring pure stands.
Based on the species-specific MERW mixing reactions represented by regression equations (6) and (7), the total relative mixing effect MERW $_{\mathrm{sp}, \mathrm{be}}$ can be estimated by the relation

$$
\mathrm{MERW}_{\mathrm{sp}, \mathrm{be}}=\mathrm{MERW}_{\mathrm{sp},(\mathrm{be})} \times m_{\mathrm{sp}}+\operatorname{MERW}_{(\mathrm{sp}), \mathrm{be}} \times m_{\mathrm{be}} .
$$

Multiplication of the respective site-specific dry mass growth by the relative mixing effects yields the absolute mixing effect $\left(\mathrm{t} \mathrm{ha}^{-1} \mathrm{y}^{-1}\right)$. Thus, both the species-specific as well as the total mixing effect on dry mass growth can be described as dependent on both the site index of the mixed species as well as the mixing proportions. Considering that $m_{\mathrm{be}}=1-m_{\mathrm{sp}}$, and supposing that the dry mass growth of Norway spruce and European beech in monoculture amounts to PAIW $_{\mathrm{sp}}$ and $\mathrm{PAIW}_{\mathrm{be}}$, the absolute mixing effect (MEA) is

$$
\begin{aligned}
\operatorname{MEAW}_{\mathrm{sp}, \mathrm{be}}= & \mathrm{MERW}_{\mathrm{sp},(\mathrm{be})} \times m_{\mathrm{sp}} \times \mathrm{PAIW}_{\mathrm{sp}}+\operatorname{MERW}_{(\mathrm{sp}), \mathrm{be}} \\
& \times m_{\mathrm{be}} \times \mathrm{PAIW}_{\mathrm{be}} .
\end{aligned}
$$




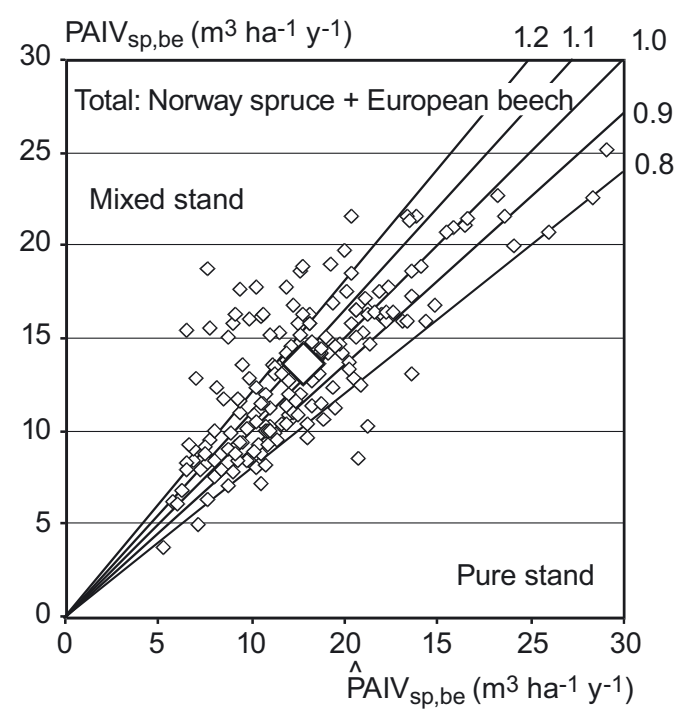

(a)

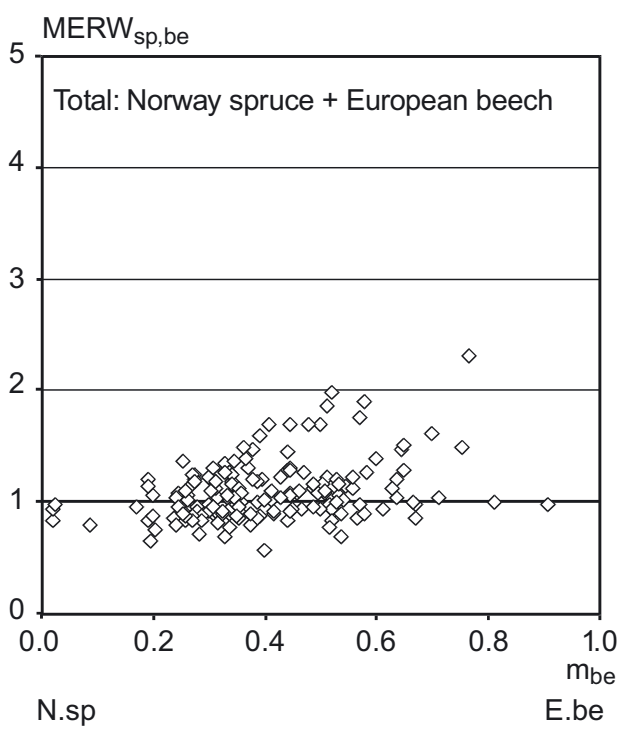

(b)

Figure 4. Comparison of periodic mean annual increment of the mixed stands with neighbouring pure stands. Depicted is (a) the observed

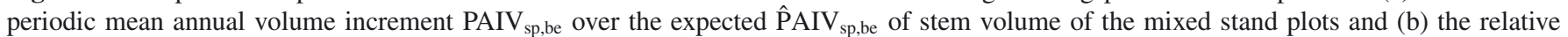
periodic mean annual above ground dry mass increment $\mathrm{MERW}_{\mathrm{sp}, \mathrm{be}}=\mathrm{PAIW}_{\mathrm{sp}, \mathrm{be}} / \hat{\mathrm{P}} \mathrm{AIW}$ sp.be over mixing proportion $\left(m_{\mathrm{be}}\right)$. On average the

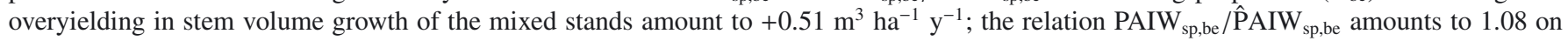
average and indicates an overyielding of $+8 \%$.

Figure 7 shows an example of the total effect of the interaction between Norway spruce and European beech for a spectrum of site conditions. Growth of mixed stands in a continuum of mixing proportions is clearly illustrated, with the left and right limits of the plot representing dry mass growth $\left(\mathrm{t} \mathrm{ha} \mathrm{y}^{-1} \mathrm{y}^{-1}\right)$ in pure Norway spruce or European beech stands. The graph demonstrates quite conclusively, that the extent of the absolute mixing effect is dependent on the dry mass growth rate of spruce and beech, the respective site indices and the mixing proportion.

On sites with high spruce productivity, the response to admixture of beech is dependent on the site index of beech. The mixing response in spruce reaches from overyielding in the case of a high site index of beech, a neutral replacement effect if sites display intermediate levels of beech productivity, to negative mixing effects on sites unfavorable to beech growth. As a consequence, mixing responses observed as overyielding, replacement, or underyielding appear not to differ categorically, but can be more concisely interpreted as individual observations belonging to a greater system of growth reaction patterns.

\section{DISCUSSION AND CONCLUSION}

\subsection{Competition and facilitation as key mechanisms in mixture}

The essential interactions between plants in mixture as well as the causes for over and underyielding are competition (resulting in growth reduction) and facilitation (resulting in growth acceleration). Competition and facilitation are frequently coupled, making them difficult to distinguish experimentally (Callaway und Walker, 1997). Through observation of over and underyielding carried out in this study, only the net effect of competition and facilitation was observed, making it impossible to distinguish between the individual positive and negative contributions of these effects on stand growth.

Depending on the site conditions, dry mass growth in the mixed stands of Norway spruce and European beech ranged from $-46 \%$ to $+138 \%$ of the growth yielded by a combination of pure stands scaled to the populations in the mixed stand (Figs. 4 and 7). Mixing appears, at least on average, to improve diameter growth in Norway spruce while reducing the standing volume and dry mass (see Fig. S1, available at www. afs-journal.org and Fig. 3). Mixing on the other hand decelerates size growth in European beech, while increasing standing volume and dry mass slightly. It should however be emphasized that despite these slight differences, pure and mixed stands do not significantly differ in terms of the achieved above ground standing volume and dry mass. This observed similarity might have resulted in part from the thinning regimes, which held the pure and mixed stands at similar densities through moderate thinning.

The species-specific mixing effects (Fig. 5) also represent the net effect of positive and negative interactions, competition and facilitation effects, without revealing in detail which positive and negative effects are actually responsible for the net result. The causal analysis of mixing effects is further complicated by the fact that the extent of competition or facilitation can be subject to change with the development phase of the stand, mixture type and site conditions (Holmgren et al., 


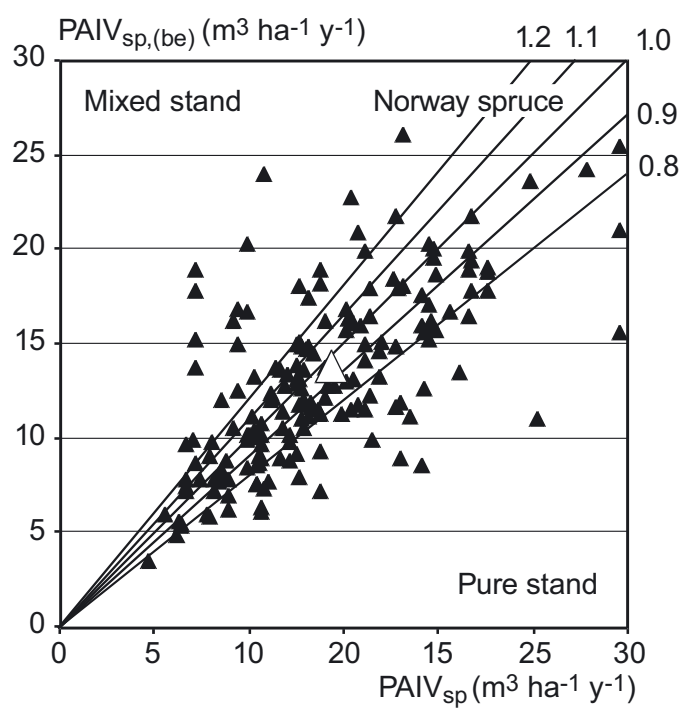

(a)

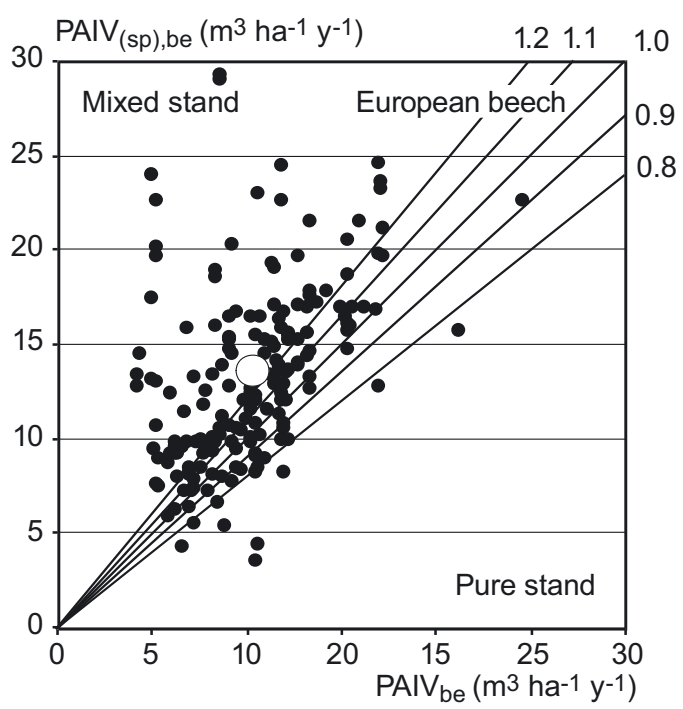

(c)

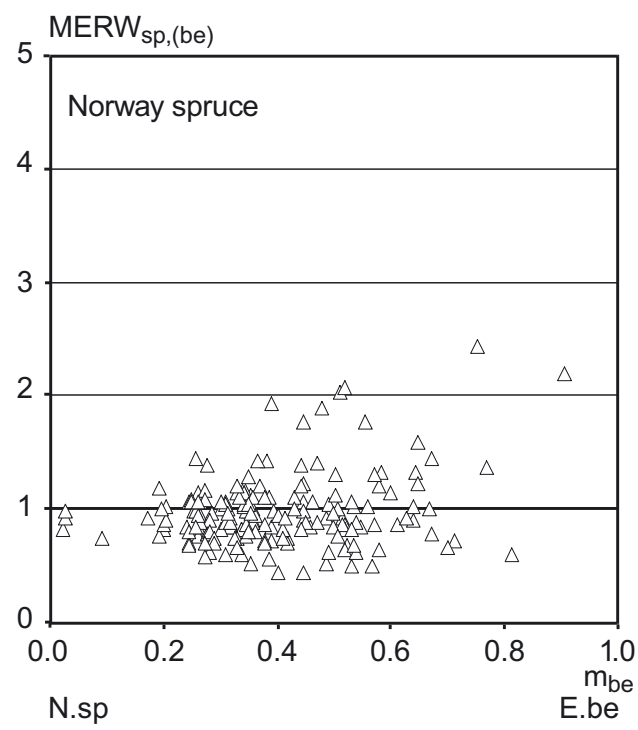

(b)

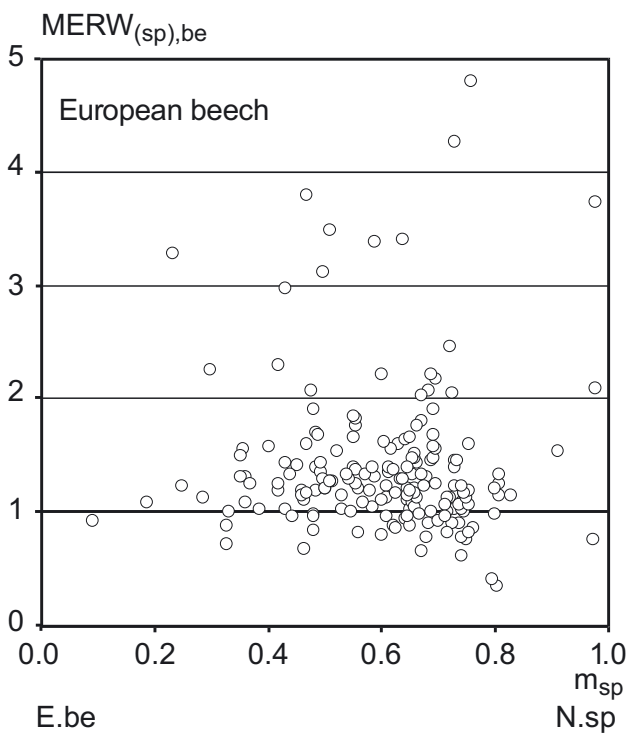

(d)

Figure 5. Comparison of the periodic mean annual increment of the mixed stands compared with the neighbouring pure stands. (a) Stem volume increment of Norway spruce in the mixed stand PAIV $\mathrm{sp}_{\text {,(be) }}$ over the respective growth in the pure stand PAIV $\mathrm{sp}_{\text {. }}$ (b) Relative periodic mean annual above ground dry mass increment MERW $_{\mathrm{sp},(\mathrm{be})}$ of Norway spruce in mixed versus pure stand PAIW $\mathrm{sp}_{\mathrm{s} \text { (be) }} / \hat{\mathrm{P}}_{\mathrm{PIW}} \mathrm{sp}$ over mixing proportion $\left(\mathrm{m}_{\mathrm{be}}\right)$. On average we find an underyielding of the mixed stands of $-0.94 \mathrm{~m}^{3} \mathrm{ha}^{-1} \mathrm{y}^{-1}$; the relation PAIW $\mathrm{Pp}_{\mathrm{spe}} / \hat{\mathrm{P}}_{\mathrm{PIW}}$ amounts to 1.01 on average and indicates an overyielding of $+1 \%$. (c) Stem volume increment of European beech in the mixed stand PAIV $(\mathrm{sp})$,be over the respective growth in the pure stand PAIV $_{\text {be }}$ (d) Relative periodic mean annual above ground dry mass increment MERW $_{(\mathrm{sp}), \mathrm{be}}$ of European

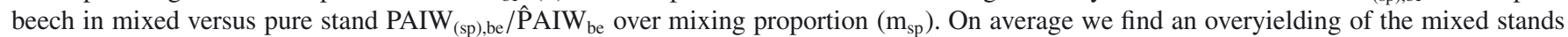
of $+2.65 \mathrm{~m}^{3} \mathrm{ha}^{-1} \mathrm{y}^{-1}$; the relation PAIW $(\mathrm{sp})$,be $/$ PAIW be amounts to 1.41 on average and indicates an overyielding of $+41 \%$.

1997). The long-term experiments used in this study do not provide sufficiently detailed information about environmental conditions and resource supplies in the stands to allow for a direct analysis of the causes for the mixing reactions. The characteristic reaction pattern along the ecological gradient does however enable inferences on the causes behind over or underyielding.

\subsection{Site-dependency of competition and facilitation}

Overyielding of the mixed stands appears to have been triggered by two separate mechanisms. On poor sites, where significant overyielding is found to have occurred quite commonly, facilitation by beech offset nutrient-related growth limitations in spruce. In contrast, overyielding of mixed stands 


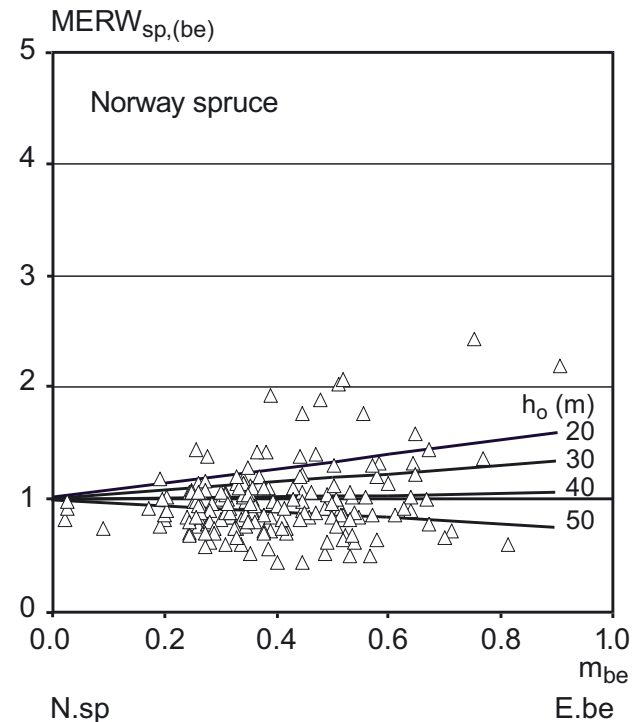

(a)

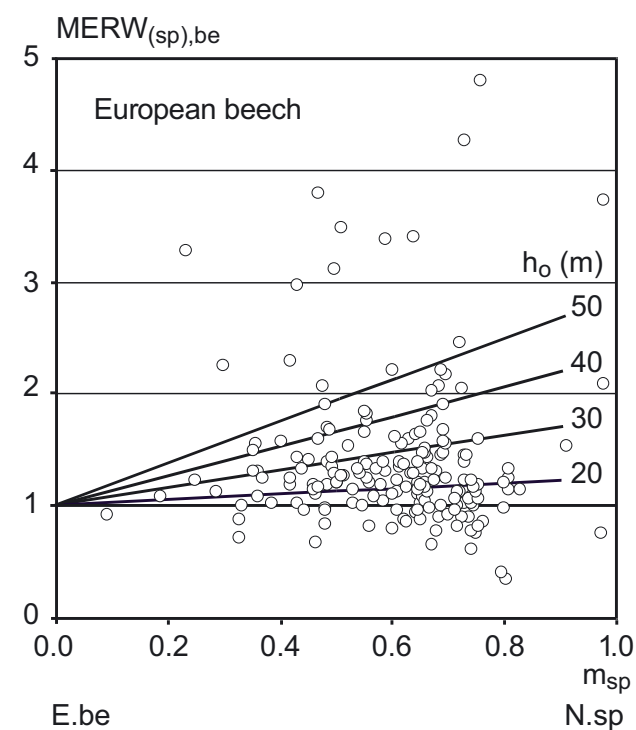

(b)

Figure 6. Mixing effect between Norway spruce and European beech in dependence on site conditions indicated by site index. (a) Relative mixing effect MERW for Norway spruce depending on the admixture of beech $\left(m_{\mathrm{be}}\right)$ and site index of Norway spruce $\left(h_{\mathrm{o}}\right)$, and $(\mathrm{b})$ Relative mixing effect MERW for European beech depending on the admixture of spruce $\left(m_{\mathrm{sp}}\right)$ and site index of European beech $\left(h_{\mathrm{o}}\right)$. MERW $=1.0$ indicates equal growth for mixed and pure stands, MERW > 1.0 and MERW < 1.0 over- and underyielding, respectively.

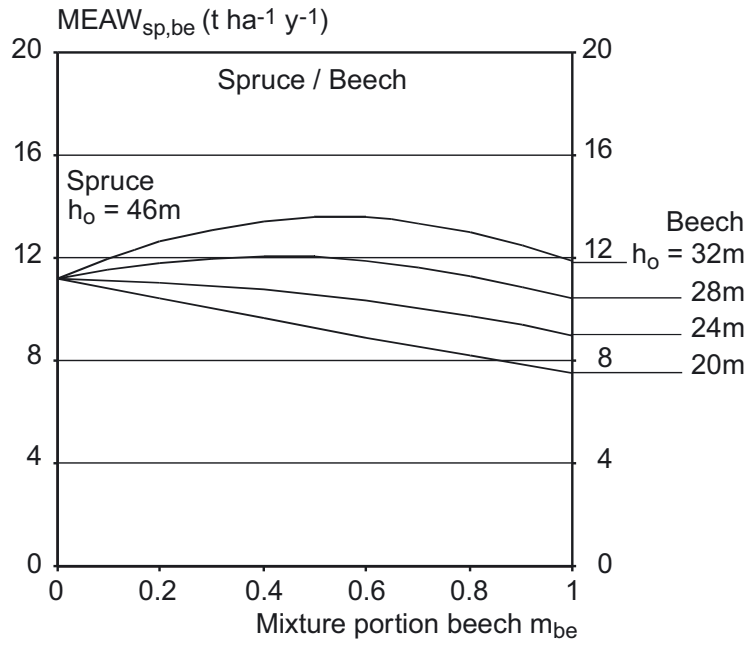

(a)

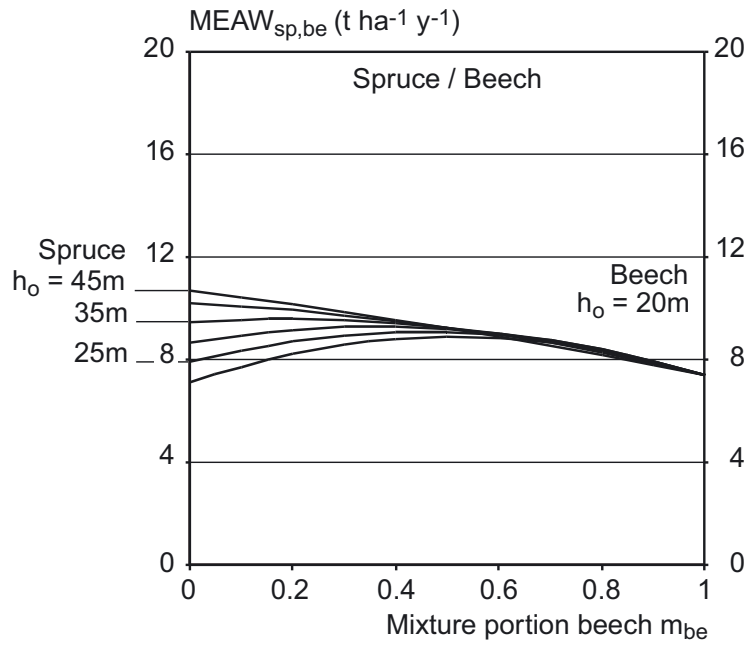

(b)

Figure 7. Effect of mixture of Norway spruce and European beech on the total above ground dry mass production MEAW in dependence on mixture proportion of beech $\left(m_{\text {be }}\right)$ and site index $\left(h_{0}\right)$ of spruce and beech. (a) Occurrence of over- and underyielding of the mixed stand depending on the site index of the involved species and (b) growing overyielding of the mixed stand with decreasing site index of Norway spruce.

occurred less frequently on rich sites, and appears to be based on an admixture effect, with spruce reducing the severe degree of intra-specific competition common in pure beech stands.

The discovery that Norway spruce is fostered by admixture of European beech on poor sites, but hindered on fertile sites may be explained as follows: On poor sites, Norway spruce profits from the substantial nutrient input from beech litter translocation and the improved decomposition and turnover of the mixed litter, which improves the water storage and has a particularly positive effect on the mineral nutrient supply. On such sites, European beech can have a positive effect on spruce, primarily through stimulation of the bioelement turnover, and by improving the nutrition of spruce. In comparison to spruce, beech litter has a higher $\mathrm{Ca}, \mathrm{Mg}$ and $\mathrm{K}$ content, as well as a lower $\mathrm{C} / \mathrm{N}$ ratio (Augusto et al., 2002). Moreover, activity of soil fauna and microflora is higher in 
beech than in spruce, resulting in a higher litter decomposition rate (Augusto et al. 2002; Wiedemann, 1942), reduced acidity, and a better humus type (Block, 1997).

However, on fertile sites admixture of beech resulted in negative effects on spruce, as beech exhibits rapid canopy and root expansion under these conditions, negatively affecting the ability of spruce to grow. Growth reduction of spruce can also be caused by competition between beech and spruce for root space and water and nutrient supply. In mixed stands a vertical separation of the root space can be observed (Fölster et al., 1991; Rothe, 1997, p. 35-38). Spruce roots can be shallower compared to those of pure spruce stands, and beech roots can even occupy the deeper regions below the roots of the neighboring spruce trees (Fölster et al. 1991, p. 99). Because of its higher transpiration rate after leaf flush, soil exsiccation is more intensive and deeper under beech than under spruce (Rothe, 1997, p. 44-53). Shallower roots and drier soil in the mixed stands during summer may have resulted in reduced access to mineral nutrients.

The finding that European beech profits considerably from admixture of spruce on fertile sites but to only a limited degree on poor sites could be explained by a saturation of intraspecific competition in the pure beech stand on fertile sites. The potential for competitive reduction by admixture of spruce is therefore also at a maximum. On poor sites, intra-specific competition in beech and the resulting self-thinning dynamics in the monoculture are less intensive, with structures more heterogeneous (Pretzsch, 2009) and the competitive release caused by admixing of spruce thus being much lower. A similar effect of intra-specific competitive reduction can be observed in pure beech stands by thinning regimes (e.g. intensive crop tree thinning) or harvest/regeneration cut techniques (e.g. target diameter harvest). The release effect and additional growth after thinning is positive on fertile sites but rather negative on poor sites; while the competitive reduction is just low in the latter it is very strong and beneficial in view on total stand growth in the former (Pretzsch, 2005). In stands where beech is highly competitive, a tendency towards closed-canopy situations is observed, and even managed stands revert to rather mono-layered, single-species conditions with the severe intraspecific competition characteristic for European beech (Otto, 1994).

The admixture of spruce can also trigger the following negative effects on beech growth: As a consequence of the usually superior height growth of spruce, beech suffers competition and reduction of growth by spruce predominantly by preemption of light (Pretzsch and Schütze, 2005; 2009). Other reasons for negative effects on beech may be the extrusion of beech roots by highly competitive spruce roots from topsoil horizons with intensive bio-element turnover, as well as net nutrient loss with beech litter drifting into spruce areas. Clearly, competitive reduction appears to be the major factor responsible for considerable facilitation and even acceleration of productivity of beech in mixture with spruce (Kelty, 1992). Because of the severe intra-specific competition synonymous with low self-tolerance in pure beech stands, admixture of almost any other species can be expected to result in a competitive reduction for beech at the stand level (Pretzsch and Biber,
2005; Zeide, 1985). If a proportion of the trees in a beech monoculture are replaced by spruce, the originally monolayered stand structure is changed towards a multilayered structure with light gaps, which enable survival of subdominant and understory beeches (Otto, 1994, pp. 210-216).

\subsection{From volume to dry mass based analysis}

Prior research into mixed forest stands has focused primarily on practical forest management, generally limiting itself to studies on wood volume production (Mettin, 1985; Rothe, 1997; Wiedemann, 1942), stability and resilience (Pretzsch, 2003; Spellmann, 1996; Lüpke and Spellmann, 1997), silvicultural practices (Petri, 1966; Wiedemann, 1951), and economics (Knoke et al., 2005; Olsthoorn et al., 1999) of pure versus mixed stands. Lüpke and Spellmann (1997) emphasize that such information is crucial to forest managers and their decision whether or not, as well as how, to establish and manage mixed stands. However, as long as mixed stand research is approached mainly from the perspective of practically relevant variables, ignoring other factors such as the quantification of dry mass production, comparison of leaf area or growth space sequestration strategies, and only questioning their immediate practical impact, the path to understanding the underlying principles of mixed stand dynamics will remain obscured (Assmann, 1961; Kelty, 1992; Kennel, 1965). We therefore agree with Assmann (1961), Burger (1941), and Kelty (1992), that a successful approach should commence with the quantification of dry matter production and allocation in pure versus mixed stands.

Stand productivity of pure versus mixed stands was therefore compared with respect to both the periodic annual growth of stem volume as well as above ground dry mass. A strong statistical relationship was found between the mixing effect calculated on the basis of stem volume growth and that of dry mass growth. When overyielding of dry mass growth in Norway spruce or European beech reached 10\%, the associated overyielding in stem volume growth amounted to about $9 \%$. This relationship is only known to have applied to the middle-aged and mature stands, as only these were considered in the study. The stem volume and dry mass constitute the major share of the total above ground volume and mass in these stands. It is not apparent whether such a strong correlation exists between stem volume and total above ground dry mass in younger and/or more structured stands, where a considerably higher proportion of dry mass is allocated to twigs, branches and leaves. Further research should consider that, particularly in young stands, mixed stands with abundant understory, or in stands with trees considerably smaller than in the adjacent mixed stands (and therefore higher proportions of non-stem wood), over- or underyielding measured in terms of dry mass may yield considerably higher differences compared to comparisons on the basis of volume growth. 


\section{CONCLUSIONS}

We conclude that silviculture can accelerate growth of spruce by admixture of beech on poor sites, while the growth of beech can be fostered by admixture of spruce, particularly on excellent sites. The site dependency of the mixing effect has far reaching implications for the response of growth at a stand level under stresses caused by events such as droughts and climate change. As illustrated by Figure 7b, Norway spruce stands cannot be expected to respond positively to an admixture of beech under favorable growth conditions. However, the lower the site index for Norway spruce, the more pronounced is the facilitation effect triggered by admixture of European beech, whereas the upper portion of the response curves in Figure $7 \mathrm{~b}$ is nearly linear, representing neutral mixing, the lower portion of the curve exhibits a concave shape and is uni-modal in pattern, showing $20 \%$ overyielding of the mixed stand. The curve system reveals that the facilitation effect of beech on spruce and the resulting overyielding is pronounced to an increasing degree with degrading site conditions for spruce.

Regarding the long-term experiments included in the study, sufficiently detailed information on site conditions was not available. For this reason, the site index was applied as a proxy and somewhat unspecific indicator for the impact of site-specific environmental conditions and resource supply on tree and stand growth dynamics. In forest growth research site index has proven to be a convenient and versatile indicator for site productivity, and was therefore considered to be adequate as a first approach tool for the classification of sites into a spectrum from low (nutrient-poor/dry) to highly productive (nutrient-rich/moist). Further investigations with a more differentiated description of long-term site conditions are however warranted, promising a more refined and causal analysis of the impact of site conditions on the mixing reactions. This more differentiated information will also pave the way to a better application of the results in practical silviculture. Site conditions under which mixing is advisable and would result in an increase in productivity can thus be distinguished from stands where it would increase competition.

In the majority of mixed stands included in the analysis of this study, the two species are intermingled within single tree mixtures, small patches, or groups. This allows for tight intertwined and synergistic niche occupation, while in mixtures of larger groups or even clusters, species grow rather similarly or, due to the extensive border zones, even less than in pure stands. Future research should address the effect of spatial mixing patterns on the mixing effect.

In order to obtain evidence of mixing effects, short term analyses in different age phases are appropriate, but long-term observations such as those analyzed in this study are crucial for correctly assessing the overall mixing effect, as well as for producing information relevant to forest management. The analyzed interaction caused by facilitation and competitive reduction represents one of several important potential mixing effects which can occur during stand development. Whether an analysis of mixture dynamics results in a surplus or deficit of productivity compared to scaled production values from pure stands, may depend on the stand development phase consid- ered in the comparison (e.g. juvenile or mature stands), length of the survey period (e.g. 2-years-period in greenhouse or 50years-survey of long-term field experiments) and other external factors (e.g. impact of damage). Mixture may result in a simple replacement effect in the initial phase, as any positive or negative interactions do not tend to occur before stand closure and interaction of both species. After canopy closure, interactions between both species can yield considerably positive effects in terms of productivity, due to facilitation and competitive reduction. In later phases, particularly in the second half of the rotation period, stand stabilization by mixture, risk distribution, and resilience may cause additional positive effects which should be within the scope of further research, as our analysis was based solely on pure and mixed stands that had grown predominately undisturbed by damage (e.g. by bark beetle, storm, snow), under no extreme thinning regimes.

Acknowledgements: We wish to thank the German Science Foundation (Deutsche Forschungsgemeinschaft) for providing the funds for mixed stand research as part of the Collaborative Research Centre 607 (Sonderforschungsbereich SFB 607) "Growth and Parasite Defense" and the Bavarian State Ministry for Nutrition, Agriculture and Forestry for permanent support of the project W 07 "Long-term experimental plots for forest growth and yield research". The included mixed stand trials belong to the networks of long-term experimental plots in Switzerland, Poland and Germany and we are deeply grateful to the respective sponsoring forest administrations. Thanks are also due to Ulrich Kern for the graphical artwork, Arman Schwarz for language revision as well as anonymous reviewers for their constructive criticisms.

\section{REFERENCES}

Arbeitskreis Standortskartierung, 1985. Forstliche Wuchsgebiete und Wuchsbezirke in der Bundesrepublik Deutschland, Landwirtschaftsverlag GmbH, Münster-Hiltrup, 170 p.

Assmann E., 1961. Waldertragskunde. Organische Produktion, Struktur, Zuwachs und Ertrag von Waldbeständen. BLV Verlagsgesellschaft, München, Bonn, Wien, $490 \mathrm{p}$.

Assmann E. and Franz F., 1965. Vorläufige Fichten-Ertragstafel für Bayern. Forstw. Cbl. 84: 13-43

Augusto L., Ranger J., Binkley D., and Rothe A., 2002. Impact of several common tree species of European temperate forests on soil fertility. Ann. For. Sci. 59: 233-253.

Block J., 1997. Disposition rheinland-pfälzischer Waldbodensubstrate gegenüber Versauerung. In: Ministerium für Umwelt und Forsten Rheinland-Pfalz: Waldschäden, Boden- und Wasserversauerung durch Luftschadstoffe in Rheinland-Pfalz, Mainz, pp. 16-27.

Block J., Roeder A., and Schüler G., 1997. Waldbodenrestauration durch Aktivierung ökosystemarer Nährstoffkreisläufe. AFZ-DerWald 1: 29-33.

Burger H., 1941. Beitrag zur Frage der reinen oder gemischten Bestände. Mitt Schweiz Anst Forstl. Versuchswesen 22: 164-203.

Callaway R.M. and Walker L.R., 1997. Competition and facilitation: a synthetic approach to interactions in plant communities. Ecology 78: 1958-1965.

Cotta von H., 1828. Anweisung zum Waldbau. Arnoldische Buchhandlung, Dresden, Leipzig.

Fölster H., Degenhardt M., Flor T., and Lux M., 1991. Untersuchungen zur Tiefendurchwurzelung und Durchwurzelungsintensität auf Braunerde-Pseudogleyen im Vorderen Hunsrück in Abhängigkeit 
von Baumart und Bestandesstrukturparametern. Mitteilungen aus der Forstl. Versuchsanstalt Rheinland-Pfalz 19/91: 91-106.

Hartig G.L., 1791. Anweisung zur Holzzucht für Förster. Neue Akademische Buchhandlung, Marburg.

Holmgren M., Scheffer M., and Huston M.A., 1997. The interplay of facilitation and competition in plant communities. Ecology 78: 19661975.

Kelty M.J., 1992. Comparative productivity of monocultures and mixed stands. In: Kelty M.J., Larson B.C., and Oliver C.D. (Eds.), The ecology and silviculture of mixed-species forests. Kluwer Academic Publishers, Dordrecht, pp. 125-141.

Kelty M.J. and Cameron I.R., 1995. Plot design for the analysis of species interactions in mixed stands. Com. For. Rev. 74: 322-332.

Kennel R., 1965. Untersuchungen über die Leistung von Fichte und Buche im Rein- und Mischbestand. Allg. Forst. Jagdztg. 136: 149161, 173-189.

Kern K.G., Moll W., and Braun H.J., 1961. Wurzeluntersuchungen in Rein- und Mischbeständen des Hochschwarzwaldes. Allg. Forst. u. Jagd Zeitung: 241-259.

Knoke T., Stimm B., Ammer C., and Moog M., 2005. Mixed forests reconsidered: A forest economics contribution on an ecological concept. For. Ecol. Manage. 213: 102-116.

Lüpke von B. and Spellmann H., 1997. Aspekte der Stabilität und des Wachstums von Mischbeständen aus Fichte und Buche als Grundlage für waldbauliche Entscheidungen. Forstarchiv. 68: 167-179.

Mettin C., 1985. Betriebswirtschaftliche und ökologische Zusammenhänge zwischen Standortskraft und Leistung in Fichtenreinbeständen und Fichten/Buchen-Mischbeständen. AFZDerWald 40: 803-810.

Olsthoorn A.F.M., Bartelink H.H., Gardiner J.J., Pretzsch H., Hekhuis H.J., and Franc A., 1999. Management of mixed-species forest: silviculture and economics, IBN Scientific Contributions 15, 389 p.

Petri H., 1966. Versuch einer standortgerechten, waldbaulichen und wirtschaftlichen Standraumregelung von Buchen-FichtenMischbeständen. Mitt Landesforstverwaltung Rheinland-Pfalz 13, $145 \mathrm{p}$.
Pretzsch H., 2005. Diversity and productivity in forests. In: SchererLorenzen M., Körner C., and Schulze E.-D. (Eds.), Forest diversity and function. Ecol. Studies 176, Springer-Verlag, Berlin, pp. 41-64.

Pretzsch H., 2009. Forest dynamics, growth and yield. From measurement to model, Springer, Berlin, Heidelberg, 664 p.

Pretzsch H. and Biber P., 2005. A re-evaluation of Reineke's rule and Stand Density Index. For. Sci. 51: 304-320.

Pretzsch H. and Schütze G., 2005. Crown allometry and growing space efficiency of Norway spruce (Picea abies (L.) Karst.) and European beech (Fagus sylvatica L.) in pure and mixed stands. Plant Biol. 7: 628-639.

Pretzsch H. and Schütze G., 2009. Trangressive overyielding in mixed compared with pure stands of Norway spruce and European beech in Central Europe: Evidence on stand level and explanation on individual tree level. Eur. J. For. Res. 128: 183-204.

Rothe A., 1997. Einfluß des Baumartenanteils auf Durchwurzelung, Wasserhaushalt, Stoffhaushalt und Zuwachsleistung eines Fichten-Buchen-Mischbestandes am Standort Höglwald. Forstl Forschungsber München 163, $174 \mathrm{p}$.

Scherer-Lorenzen M., Körner C., and Schulze E.-D., 2005. Forest diversity and function. Ecol. Studies 176, Springer-Verlag, Berlin, Heidelberg, 399 p.

Spellmann H., 1996. Leistung und Windstabilität von Fichten-BuchenMischbeständen. Tagungsbericht Dt Verb Forstl Forschungsanst, Sek Ertragskd, in Neresheim, S. 46-56.

Wiedemann E., 1942. Der gleichaltrige Fichten-Buchen-Mischbestand. Mitt. Forstwirtsch. u. Forstwiss. 13: 1-88.

Wiedemann E., 1951. Ertragskundliche und waldbauliche Grundlagen der Forstwirtschaft. JD Sauerländer's Verlag, Frankfurt am Main.

Otto H.-J., 1994. Waldökologie. UTB für Wissenschaft, Eugen Ulmer, Stuttgart.

Schober R., 1975. Ertragstafeln wichtiger Baumarten. JD Sauerländer's Verlag, Frankfurt am Main.

Zeide B., 1985. Tolerance and self-tolerance of trees. For. Ecol. Manage. 13: $149-166$. 